\title{
An Evidence Based Case of Planter Psoriasis Treated by Individualized Homoeopathic Medicine
}

\author{
Sanjukta Mandal, ${ }^{1}$ Bikash Biswas ${ }^{2 *}$ \\ ${ }^{1}$ PGT, Department of Materia Medica, ${ }^{2}$ PGT, Department of Case Taking and Repertory, \\ Mahesh Bhattacharyya Homoeopathic Medical College \& Hospital, Bholanath Chakraborty \\ Road, Doomurjola, District- Howrah West Bengal, India
}

\begin{abstract}
:
Psoriasis is a non-contagious, inflammatory disease of the skin that results in itchy, scaly patches on different parts of the body. This disorder causes skin cells to multiply at an abnormally faster rate. The patients depict an unpredictable course of remission and relapse; winter aggravation is common. Conventional treatment involves application of topical ointments, steroids, anti-inflammatory and immunosuppressive drugs. Homoeopathy is a popular alternative from of treatment in this type of skin conditions. The person is treated as a whole and a suitable constitutional remedy is prescribed, so that there is very less chance of relapse of symptoms. The patient's general condition, mental status along with the symptoms of psoriasis is considered during finding the similimum remedy. In this case of chronic planter psoriasis an individualised homoeopathic medicine has been prescribed. A female patient suffered from painful cracks, exfoliating scales and slight itching of the soles. This condition is termed as "Planter Psoriasis". The case came to the surgery OPD of MBHMC\&H. We constructed a totality of the patient and based on that a similimum was selected after Repertorization and consultation with the Homoeopathic Materia Medica. The case was well managed with Homoeopathic medicine "Graphites" and there was no remission of symptoms in the following winter.
\end{abstract}

Keywords: Homoeopathy, Hompath repertory software, Individualization, Psoriasis, Planter Psoriasis.

Received: 06.05.2021 Revised: 19.06.2021 Accepted: 25.06.2021 Published: 28.06.2021

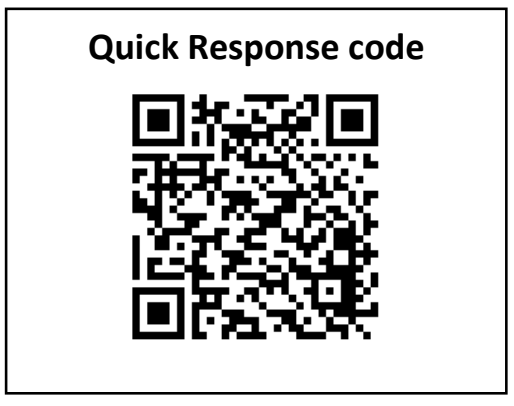

*CORRESPONDING AUTHOR:

\section{Dr. Bikash Biswas}

PGT, Department of Case Taking and Repertory,

Mahesh Bhattacharyya Homoeopathic Medical College

\& Hospital, Bholanath Chakraborty Road, Doomurjola,

District- Howrah West Bengal, Pin-711104

E-mail : bikash21592@gmail.com 


\section{Introduction:}

Psoriasis is a chronic and recurrent disorder. The classic lesion is a well-marginated, erythematous plaque with silvery white surface scale. Distribution includes extensor surfaces (i.e., knees, elbows, and buttocks); may also involve palms, planter surface and scalp (particularly anterior scalp margin). The associated findings include psoriatic arthritis and nail changes (onycholysis, pitting or thickening of nail plate with accumulation of subungual debris) ${ }^{[1]}$. The cause is unknown but may be autosomal dominant or familial, resulting from physical trauma, infections, drugs and immunological factors. ${ }^{[2]}$ Prevalence roughly $1 \%$ of population is affected, but less than half require aggressive treatment.

It can occur at any age but two peaks are generally seen, the early onset peak incidence is seen at 22.5 years. This indicates more severe disease and such patients usually have positive family history. The late onset peak incidence is seen at 45.5years ${ }^{[2]}$. Both sexes are equally affected. Most patients are worse particularly in winter season. Planter psoriasis is a variant of psoriasis which affects the skin of soles, with hyperkeratotic changes, pustuler changes and with bmixed morphologies. [3] The exact cause is unknown, however it caused by genetic and environmental factors. The most common genetic factor of planter psoriasis is human leucocyte antigen (HLA) Cw6. There may also be possible linkage of CARD14 gene. ${ }^{[4-6]}$ Planter psoriasis has also been linked with smoking, thyroid disease, and arthritis of the anterior thorax. ${ }^{[7]}$

Besides the general discomfort resulting from the skin affection of psoriasis, it also causes cosmetic disfigurement and lack of confidence in the affected individuals. Applications of ointments and steroids have many side effects and chances of recurrence of symptoms are also high. So, patients often opt for alternative medicinal therapies such as homoeopathy as it is much cost effective and chances of recurrence are low.
Psoriasis has to be differentiated from other skin conditions such as eczema, atopic dermatitis, palmo-pustular dermatitis, contact dermatitis, etc. Patients with psoriasis have an increased risk of developing diabetes, high blood pressure, crohn's disease, arthritis, anxiety, depression etc. Thus, it is very important to cure this disease through internal medicines that consider the whole individual as one entity and all the physical, mental and disease symptoms are evaluated during prescription.

A number of research papers have showed that homoeopathy is being successfully employed for treating psoriasis. A prospective observational study with patients suffering from psoriasis has shown evidence that under classical homoeopathic treatment; patients with psoriasis had improvement of symptoms and quality of life. ${ }^{[8]}$ Other articles with case series on psoriasis have also depicted the positive effects of homoeopathic treatment in different forms of psoriasis. ${ }^{[9-11]}$

\section{Case History:}

A 44-year-old lady came to Mahesh Bhattacharyya Homoeopathic Medical College and Hospital $04^{\text {th }}$ October 2018, reported with complaints with planter psoriasis of both feet. She was suffering from white scaly plaque like eruption with crack on both sole with blackish discoloration, which was painful on walking on floor or hard surface. There was occasional itching in that particular area. There was a sticky discharge which got aggravated on getting feet wet. This condition was most troublesome during every winter. Her nature very timid and mild natured. Patient was much apprehensive about her future and about her skin condition. She was so chilly that even in summers she needed coverings. She had tendency to catch cold and suffer from inflammation of various kinds, like tonsil and ear. All complaints were aggravated in winter. She had great aversion for sweet, meat and hot food and drinks. She had a particular craving 
for cold food and milk. She had constipation since childhood, her bowels were irregular and experienced much pain during passing stool. Her menses were late with excoriating leucorrhoea during menstruation. She had aversion for coition from the very beginning of her sexual life. She was under treatment of allopathic mode of treatment in the last 2 years but there was no improvement at all.

Her past history revealed that, she had a history of mumps at the age of 8 years. She had a history of surgery for acute appendicitis and a history of spontaneous abortion at $2^{\text {nd }}$ month of first pregnancy. Her family history revealed that her father died due to CVA (Cardio vascular attack). Mother had osteoarthritis and thyroid dysfunction. No other history was detailed by the her.

\section{Miasmatic Analysis:}

This is a mixed miasmatic case but the symptoms of psora and syphilis are predominant, which points towards a tubercular state. ${ }^{[12]}$ Points in favour of psora are- white scaly eruption on both sole, constipation, desires milk, easily catches cold, tendency to inflammation and winter aggravation. The points in favour of syphilitic miasm are crack of both sole with blackening, history of abortion, chilly patient, desire for cold food and aversion hot food.

\section{Evaluation of symptoms:}

- Patient is very timid in nature.

- Very much apprehensive

- White erythematous scaly plaque on both feet from 2 year.

- Cracks of both sole.

- Slight itching in soles.

- Blackening colour of cracks.

- Slightly painful.

- Aggravation in every winter season.

- Sticky discharge on getting wet.

- Chilly patient.

- Easily catches cold in every winter season.

- Aversion for sweet.

- Aversion meat.

- Aversion Hot food

- Desire cold food and milk.

- Chronic constipation from childhood.

- Menses too late and irregular.

- Aversion to coition.

- Tendency to inflammation.

\section{Remedy selection:}

After thorough case taking, evaluation of symptoms, Repertorization ${ }^{[13]}$ and consultation with the Materia Medica ${ }^{[14]}$, Graphites 200- 2 doses was prescribed on 9th of September, 2020. The patient was asked to report after 28 days. 


\section{Reportorial analysis:}



Figure 1: Repertorial analysis using Hompath FireFly mobile app (Kent's repertory)

Table-1: Follow up and prescription:

\begin{tabular}{|c|c|c|}
\hline Date & Symptoms & Prescription \\
\hline $\begin{array}{l}04^{\text {th }} \\
\text { October } \\
2018\end{array}$ & $\begin{array}{l}\text { she was suffering from white scaly plaque like eruption with } \\
\text { crack on both sole with blackish discoloration, which was } \\
\text { slightly painful on walking on floor or hard surface. There is } \\
\text { slight sticky discharge which is aggravated on getting feet wet. } \\
\text { Aggravated in every winter. Her nature was so timid and so } \\
\text { mild. All complaints were aggravated in winter. She had great } \\
\text { aversion for sweet, meat and hot food and drinks. She had a } \\
\text { craving for cold food and milk. She had constipation since } \\
\text { childhood, irregular habit and so painful during stool. She had } \\
\text { late menses with excoriating leucorrhoea during menstruation. } \\
\text { She had aversion for coition from very beginning. }\end{array}$ & $\begin{array}{l}\text { Graphites } 200 / 2 \\
\text { doses in sac lac } \\
\text { ODAC X } 2 \text { DAYS } \\
\text { Followed by } \\
\text { placebo (globule } \\
\text { no } 20 \text { moistened } \\
\text { with a few drops of } \\
\text { rectified spirit) for } \\
21 \text { days. } \\
4 \text { globules every } \\
\text { morning x } 21 \text { days }\end{array}$ \\
\hline $\begin{array}{l}25^{\text {th }} \\
\text { October }\end{array}$ & $\begin{array}{l}\text { No significant improvement of that particular area. Colour of } \\
\text { sole was still black. Cracks of both soles were remained same. }\end{array}$ & $\begin{array}{l}\text { Placebo for } 21 \\
\text { days. }\end{array}$ \\
\hline
\end{tabular}


INTERNATIONAL JOURNAL OF AYUSH CASE REPORTS (IJA-CARE)

\begin{tabular}{|c|c|c|}
\hline 2018 & $\begin{array}{l}\text { There was sticky discharge same as before, white scaly eruption } \\
\text { remained same as before. Other vitals were same as before. }\end{array}$ & $\begin{array}{l}4 \text { globules every } \\
\text { morning x } 21 \text { days }\end{array}$ \\
\hline $\begin{array}{l}08^{\text {th }} \\
\text { November } \\
2018\end{array}$ & $\begin{array}{l}\text { There was reduced discharge and blackening of cracks was } \\
\text { slghtly reduced. Plaques were same as before. Scales were } \\
\text { exfoliated and raw in colour. } \\
\text { Other vitals were same as before. } \\
\text { Patient generally doing well }\end{array}$ & $\begin{array}{l}\text { Placebo for } 21 \\
\text { days. } \\
4 \text { globules every } \\
\text { morning x } 21 \text { days }\end{array}$ \\
\hline $\begin{array}{l}29^{\text {th }} \\
\text { November } \\
2018\end{array}$ & $\begin{array}{l}\text { All complaints were better than before no discharge from } \\
\text { cracks, blackening of skin was still same. But cracks were } \\
\text { better and pain also reduced. Now patient had regular stool and } \\
\text { generally doing well. }\end{array}$ & $\begin{array}{l}\text { Placebo for } 21 \\
\text { days. } \\
4 \text { globules every } \\
\text { morning x } 21 \text { days }\end{array}$ \\
\hline $\begin{array}{l}20^{\text {th }} \\
\text { December } \\
2018\end{array}$ & $\begin{array}{l}\text { No discharge from sole. Exfoliation of skin reduced and } \\
\text { rawness of both soles were reduced and no pain in sole. No new } \\
\text { symptoms. Patient doing very well. }\end{array}$ & $\begin{array}{l}\text { Placebo for } 21 \\
\text { days. } \\
4 \text { globules every } \\
\text { morning x } 21 \text { days }\end{array}$ \\
\hline $\begin{array}{l}10^{\text {th }} \\
\text { January } \\
2019\end{array}$ & $\begin{array}{l}\text { There was No cracks in in both feet, no blackening of sole. No } \\
\text { discharge no irritation was there. } \\
\text { Scaly plaques were reduced and smooth normal skin surface } \\
\text { was there. No new complaints. Patient doing very well. }\end{array}$ & $\begin{array}{l}\text { Placebo for } 21 \\
\text { days. } \\
4 \text { globules every } \\
\text { morning x } 21 \text { days }\end{array}$ \\
\hline $\begin{array}{l}07^{\text {th }} \\
\text { February } \\
2019\end{array}$ & $\begin{array}{l}\text { Menses regular from previous month, patient had regular stool } \\
\text { and leucorrhoea was reduced during menses. } \\
\text { Both sole with normal skin surface. There were plaques, there } \\
\text { was no blackening discoloration. There were no cracks. Patient } \\
\text { doing well. }\end{array}$ & $\begin{array}{l}\begin{array}{l}\text { Placebo for } 21 \\
\text { days. } \\
4 \text { globules every } \\
\text { morning x } 21 \text { days }\end{array}\end{array}$ \\
\hline $\begin{array}{l}28^{\text {th }} \\
\text { February } \\
2019\end{array}$ & Patient doing well no new symptoms. & $\begin{array}{l}\text { Placebo for } 21 \\
\text { days. } \\
4 \text { globules every } \\
\text { morning x } 21 \text { days }\end{array}$ \\
\hline
\end{tabular}

\section{Clinical images:}

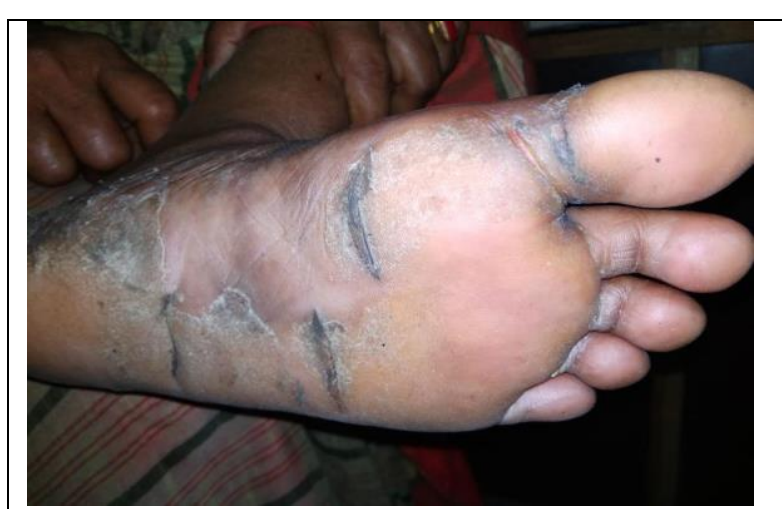

Fig-2: Before treatment left foot

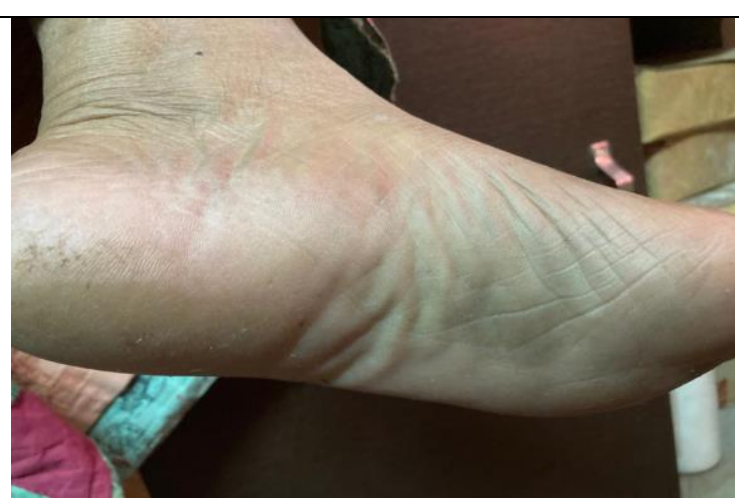

Fig-3: After treatment left foot 


\section{INTERNATIONAL JOURNAL OF AYUSH CASE REPORTS (IJA-CARE)}

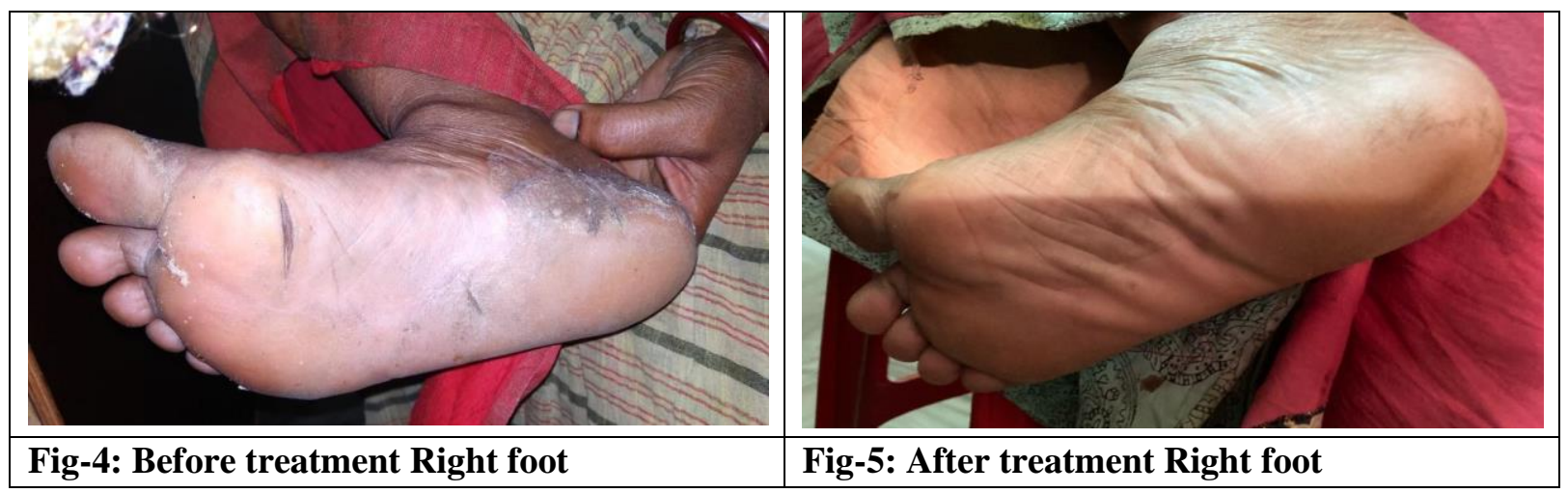

\section{Discussion:}

The patient first visited the OPD on $4^{\text {th }}$ October, 2018 (figure 2 and figure 3). She underwent homoeopathic treatment with very good improvement. The above discussed case was very nicely managed with classically selected homoeopathic medicine. She was treated with Graphites 200c- 2 doses followed by placebo for about 5 months with remarkable improvement of her skin condition (figure 4 and figure 5) as well as her constipation and irregular menses. She stopped attending OPD after that but on December, 2019 she came to our OPD again as she was worried that her skin symptoms might return again. But there was no relapse of symptoms and the patient was healthy.

Homeopathy follows a holistic approach where a particular symptom is not considered for prescription, rather all physical general and mental general symptoms are considered for proper individualization of the case. After forming a totality, Graphites was selected considering all the symptoms of the patient. The selected medicine Graphites is well known for its special action on the skin symptoms. Dr Hahnemann's proving and observations have defined its powers over skin affections. The other symptoms such as constipation and irregular menses were also cured as the remedy selected was constitutional. There was an overall improvement of the patient besides her main skin complaint. Hope that this wonderful case will benefit the physicians in treating many more such cases with confidence.

\section{Conclusion:}

On the basis of this single case study it is concluded that Homoeopathic medicine "Graphites is effective in Planter Psoriasis with long term effect without recurrence.

\section{Limitation of the study:}

This is single case report and further study can be-planned in more number of patients to establish its $f$ efficacy.

\section{Consent of patient:}

The consent of patient was dully taken at the time for registration as per ethics for treatment and publication without disclosing the identity of patient.

\section{References:}

1. Longo. D L, Fauci AS, Kasper. DL, Hauser S L, Jameson JL, Loscalzo J, Harrison's Manual of Medicine, $18^{\text {th }}$ edition, Mc Graw Hill publication, p-369370.

2. Khanna. N, Illustrated synopsis of Dermatology and Sexually Transmitted diseases, 4th edition Elsevier,2011, common pattern of eczema, Atopic dermatitis, p- 40-44.

3. Farley E, Masrour S, McKey J, Menter A. Palmoplantar psoriasis: a phenotypical and clinical review with introduction of a new quality-of-life assessment tool. J Am Acad Dermatol. 2009;60(6):1024-31. [PubMed] 
4. Asumalahti K, Ameen M, Suomela S, Hagforsen E, Michaëlsson G, Evans J, Munro M, Veal C, Allen M, Leman J, David Burden A, Kirby B, Connolly M, Griffiths CE, Trembath RC, Kere J, Saarialho-Kere U, Barker JN. Genetic analysis of PSORS1 distinguishes guttate psoriasis and palmoplantar pustulosis. $\mathbf{J}$ Invest Dermatol. 2003;120(4):627-32. [PubMed]

5. Kingo K, Mössner R, Kõks S, Rätsep R, Krüger U, Vasar E, Reich K, Silm H. Association analysis of IL19, IL20 and IL24 genes in palmoplantar pustulosis. Br J Dermatol. 2007;156(4):646-52. [PubMed]

6. Coto-Segura $\mathrm{P}$, González-Fernández $\mathrm{D}$, Batalla A, Gómez J, González-Lara L, Queiro R, Alonso B, Iglesias S, Coto E. Common and rare CARD14 gene variants affect the antitumour necrosis factor response among patients with psoriasis. $\mathrm{Br}$ J Dermatol. 2016;175(1):134-41 .

7. Witt CM, Lüdtke R, Willich SN. Homeopathic treatment of patients with psoriasis--a prospective observational study with 2 years follow-up. Journal of the European Academy of Dermatology and Venereology: JEADV.2009; 23(5): 538-543.

8. Nwabudike LC. Psoriasis and homeopathy. Proc Rom Acad Series B. 2011; 3:237-42.

9. Nwabudike LC. Palmar and plantar psoriasis and homeopathy - Case reports. Our Dermatol Online. 2017;8(1):66-69
10. Rahman S, Dey JK (2018). A case report of plantar psoriasis treated with homoeopathy. J Homoeopathic Links. 2018; 31 (04): 248-253.

11. Allen JH. The chronic miasms with repertory, revised edition, rearranged and augmented edition:2007. B Jain Publisher (P) Ltd. [Last Accessed on $4^{\text {th }}$ October, 2020]

12. Hompath Fire Fly mobile app a repertory software, using Kent's repertory, mind technologies Pvt. Ltd. [Last Accessed on $4^{\text {th }}$ October, 2020]

13. Boericke W. Pocket Manual of Homoeopathic Materia Medica Comprising the Characteristic and Guiding Symptoms of all Remedies, $9^{\text {th }}$ edition revised and enlarged with the addition of a repertory by Oscar E. Boericke, 2003, Modern homoeopathic publication, p- 309312.

Conflict of interest: Author declares that there is no conflict of interest.

Guarantor: Corresponding author is guarantor of this article and its contents.

\section{Source of support: None}

\section{How to cite this article:}

Mandal S, Biswas B. An Evidence Based Case of Planter Psoriasis Treated by Individualized Homoeopathic Medicine. Int. J. AYUSH CaRe. 2021; 5(2):84-90. 